\title{
Evaluation of the possibility of $C$. burnetii transmission by the alimentary route in a guinea pig model
}

\author{
Agnieszka Jodełko ${ }^{1}$, Monika Szymańska-Czerwińska ${ }^{1}$, \\ Anna Kycko ${ }^{2}$, Krzysztof Niemczuk ${ }^{1}$ \\ ${ }^{1}$ Department of Cattle and Sheep Diseases, ${ }^{2}$ Department of Pathology, \\ National Veterinary Research Institute, 24-100 Puławy, Poland \\ monika.szymanska@piwet.pulawy.pl
}

Received: June 4, 2019 Accepted: August 12, 2019

\begin{abstract}
Introduction: Q fever (coxiellosis) is an infectious disease of animals and humans, caused by C. burnetii and widely distributed throughout the world. It is known that people and animals acquire the disease predominantly via inhalation of infectious aerosols. The possibility of transmission of the pathogen by the alimentary route is still a matter of debate and remains controversial. Therefore the aim of this study was to fill the gaps in knowledge of oral transmission of $C$. burnetii by conducting biological tests on the guinea pig model. Material and Methods: Guinea pigs, divided into five groups comprising a negative control and four experimental groups, received specified concentrations of $C$. burnetii per os. To determine the presence of specific antibodies, blood samples were tested using CFT. Also, internal organs collected during necropsy were screened by a real-time PCR targeting IS1111. Additionally, histopathological evaluation of the tissues was performed. Results: The presence of antibodies and pathogen DNA in caecum was confirmed in one guinea pig from experimental group IV. C. burnetii was also detected in testicular tissue collected from one animal of experimental group II. Conclusions: The presence of pathogen DNA in the testicular tissue indicates that infection spreads haematogenously. In the majority of experimental animals specific antibodies and genetic material of C. burnetii were not detected. This fact suggests that development of infection depends on many factors, such as animal immune status.
\end{abstract}

Keywords: guinea pig, Coxiella burnetii, alimentary route, infection.

\section{Introduction}

Q fever is a widespread zoonotic disease caused by the obligate intracellular microorganism Coxiella burnetii. This Gram-negative bacterium can infect a wide range of hosts, including humans, wild and domestic mammals, birds, reptiles, and arthropods $(1,13,21)$. Clinical symptoms of Q fever in both humans and animals are various and nonspecific, moreover infections often remain asymptomatic. The environment becomes contaminated with the bacteria mainly due to its excretion by infected ruminants (i.e. cattle, sheep, and goats). The highest numbers of $C$. burnetii are shed in birth products during abortion or parturition, and it is also passed out of the body in milk, faeces, urine, and semen $(9,14)$. It is assumed that people and animals contract the disease predominantly by inhalation of infectious aerosols or direct contact with affected individuals or contaminated animal products. Some research indicates that the consumption of unpasteurised milk may be a cause of infection $(17,19)$, and the presence of viable $C$. burnetii was demonstrated in raw bovine milk $(7,12)$. Nevertheless, debate continues on this mode of transmission and a direct link between development of Q fever and ingestion of contaminated raw milk needs to be confirmed.

Since the discovery of C. burnetii in the 1930s, many animal models have been used to investigate the pathogenesis of $\mathrm{Q}$ fever and evaluate the protection abilities of developed vaccines (4). It has been demonstrated that immunocompetent mice are less susceptible to C. burnetii infection than guinea pigs (16). The latter species is known as a very good animal model of acute $\mathrm{Q}$ fever in humans, with fever being the primary indicator of the disease (8). In this study we attempted to fill the gaps in knowledge of oral transmission of the pathogen and utilised a guinea pig model to assess the morbidity and mortality after per os administration of 
phase I C. burnetii Nine Mile strain. Taking into consideration the increasing consumption of raw milk and artisanal dairy products, this study is significant for the protection of the public's health.

\section{Material and Methods}

Strain cultivation and the preparation of infective inoculum. The African green monkey kidney (VERO) cells were cultivated in minimum essential medium (MEM) (Sigma-Aldrich, USA) supplemented with $10 \%$ foetal bovine serum (PAN-Biotech, Germany) at $37^{\circ} \mathrm{C}$ in the presence of $5 \% \mathrm{CO}_{2}$. The phase I Nine Mile RSA493 strain, kindly provided by Wageningen University \& Research (the Netherlands), was used to inoculate the cell line. The infected cells were passaged twice at seven-day intervals. The cytopathic effect and the number and size of phagolysosome-like vacuoles containing $C$. burnetii cells were microscopically assessed daily. After incubation, the culture media from all the bottles were collected and pooled. Then $12 \mathrm{~mL}$ of PBS was added to each bottle, the cells were scraped and obtained suspensions were also pooled. Collected medium and cell suspension were sonicated and centrifuged at $500 \times \mathrm{g}$ for $10 \mathrm{~min}$ in $15 \mathrm{~mL}$ Falcon tubes. The supernatant was collected into Eppendorf tubes and then centrifuged for one hour at $24,400 \times \mathrm{g}$. Next, the supernatant was rejected and the remaining pellet was resuspended in $400 \mu \mathrm{L}$ PBS per Eppendorf tube (sludge from the culture medium) or in $800 \mu \mathrm{L}$ PBS per Eppendorf tube (cell suspension). This solution was subsequently filtered using sterile filters with pore sizes of 1.2 and $0.45 \mu \mathrm{m}$. To determine $C$. burnetii concentration after purification, 10 -fold serial dilutions of the filtrate were prepared in sterile PBS (to $10^{-6}$ ) and stained with a LIVE/DEAD BacLight Bacterial Viability Kit (Thermo Fisher Scientific, USA) following the manufacturer's instructions. Additionally, a realtime PCR targeting com 1 was performed as described by Lockhart et al. (11). Then suitable dilutions of bacteria were prepared, aliquoted, and frozen at $-80^{\circ} \mathrm{C}$. Before starting the experiment, the dilutions were defrosted and the concentration of viable bacteria was checked with the LIVE/DEAD ${ }^{\circledR}$ BacLight Bacterial Viability Kit. The cultivation of the $C$. burnetii strain was performed in BSL3 (Biosafety Level 3) laboratory conditions.

Guinea pigs. Fifteen 6-7-week-old in-house bred (NVRI, Poland) guinea pigs (Cavia porcellus) weighing 400-450 g were used in the experiment. Animals were housed in individual cages, each group in a separate room, in a BSL 3 facility with a $12 \mathrm{~h}-12 \mathrm{~h}$ light-dark cycle. The number of air exchanges was 12 per hour and temperature and humidity were maintained between $18-25^{\circ} \mathrm{C}$ and $40-60 \%$, respectively. The animals were given water and commercial LSK guinea-pig feed (Agroprod, Poland) ad libitum. Vitamin $\mathrm{C}$ was administered at $10 \mathrm{mg} / \mathrm{kg}$ b.w. orally every day to prevent its deficiency. To reduce stress-related abnormalities, guinea pigs were acclimated to the facility for two weeks prior to the experiment. They were randomly divided into five groups: a negative control group $(n=3)$ and four experimental groups (each $n=3$ ). Prior to the start of the experiment, blood and faecal samples were collected from all animals for serological and molecular analyses to exclude the possibility of $C$. burnetii infection. The guinea pigs' health was assessed daily and rectal temperature and behaviour were recorded.

Infection. The experiment lasted 12 weeks. Guinea pigs in the control group received $1 \mathrm{~mL}$ of sterile PBS solution applied by syringe directly into the mouth every 48 hours. Animals from experimental group I received $1 \mathrm{~mL}$ of inoculum containing $10^{2}$ of $C$. burnetii cells $/ \mathrm{mL}$ once by the same route. Doses of $1 \mathrm{~mL}$ of $10^{2}$ C. burnetii cells were administered per os every 48 hours to guinea pigs in experimental group II. Animals belonging to group III received $1 \mathrm{~mL}$ of bacterial suspension containing $10^{6} \mathrm{C}$. burnetii orally once. Individuals in group IV were given $1 \mathrm{~mL}$ of the inoculum containing $10^{6}$ bacterial cells every 48 hours. General physical examination of guinea pigs from all groups was carried out daily, and blood from all animals was collected to determine the titres of specific antibodies on days 5 and 7 and then weekly during the experiment. After 12 weeks the guinea pigs were euthanised by intravenous injection of pentobarbital sodium at a dose of $100 \mathrm{mg} / \mathrm{kg}$ b.w. Then the heart, lungs, liver, spleen, testes, stomach, caecum, and small intestine of all animals were collected during the autopsy.

Histopathology. Tissues collected at post-mortem examination were fixed in $10 \%$ neutral buffered formalin, embedded in paraffin, cut into $5 \mu \mathrm{m}$ slices, and routinely stained with haematoxylin-eosin (HE). Microscopic examination was performed using an Axiolab microscope (Zeiss, Germany).

Serology. Blood samples were stored at room temperature for $30-45 \mathrm{~min}$ to allow clotting and then centrifuged at $1,000 \times \mathrm{g}$ for $10 \mathrm{~min}$ to obtain serum. Then, serum specimens were tested for the presence of antibodies to $C$. burnetii using a complement fixation test (CFT). Detection of phase-specific IgM and IgG was performed utilising reagents supplied by Virion/Serion (Germany), and their instructions were followed in measuring antibody levels. The inactivation temperature of the sera was $56 \pm 1^{\circ} \mathrm{C}$, the initial dilution of the sample was 1:5, and the final dilution was 1:80. Serum was considered positive when at least partial inhibition of haemolysis $(+)$ was observed in the dilution 1:10.

Real-time PCR. Extraction of DNA from faeces and tissue specimens collected at post-mortem examination was performed using a QIAamp DNA Stool Mini Kit and DNeasy Blood \& Tissue Kit (Qiagen, Germany). Extraction procedures were performed as the manufacturer directed and DNA aliquots were stored at $-20^{\circ} \mathrm{C}$ until use.

All DNA extracts were screened for the presence of C. burnetii IS 1111 by real-time PCR according to Capuano et al. (5), including a commercial internal amplification control - TaqMan Exogenous Internal Positive Control (Thermo Fisher Scientific, USA) - to 
monitor PCR inhibitors and including a panel of required positive and negative controls in each run. The procedure was validated under laboratory conditions. The real-time PCR was performed using the 7500 Fast Real-Time PCR system v 2.3 (Applied Biosystems, USA). For the analytical cut-off, a value of 36.0 was selected, corresponding to the defined lower limit of detection of the test.

\section{Results}

Serological analyses of blood and molecular tests of faeces performed before the experiment were negative. Animals from the control group and all experimental groups did not present the clinical symptoms of coxiellosis. No abnormalities were found, nor did the internal body temperature of all individuals exceed normal temperature ranges $\left(37.4^{\circ} \mathrm{C}\right.$ to $\left.39.5^{\circ} \mathrm{C}\right)$. The guinea pigs were thriving, eagerly took feed and defecated normally. Serological tests of sera confirmed the presence of specific antibodies in animal 4.2 from experimental group IV. Antibodies to phase II antigens were detected from the $21^{\text {st }}$ day of the experiment, and immunoglobulins against phase I were noted on days 77 and 84 post infection. In all other guinea pigs from the control group and from the experimental groups, no seroconversion was observed (Table 1).

The results of molecular analysis of internal organ homogenates are summarized in Table 2. The presence of $C$. burnetii DNA was confirmed by real-time PCR in two tested specimens. One of them was a sample of testicular tissue collected from animal 2.2 from experimental group II. Pathogen genetic material was also detected in the caecum of animal 4.2 from experimental group IV.

Histopathological examination of collected tissues did not reveal pathological changes that could indicate C. burnetii infection.

Table 1. Results of CFT performed on guinea pig serum specimens

\begin{tabular}{|c|c|c|c|c|c|c|c|c|c|c|c|c|c|c|c|}
\hline \multirow{3}{*}{ Group } & \multirow{3}{*}{$\begin{array}{l}\text { Animal } \\
\text { ID }\end{array}$} & \multicolumn{14}{|c|}{ Result of CFT* } \\
\hline & & \multicolumn{14}{|c|}{ Day of experiment } \\
\hline & & 0 & 5 & 7 & 14 & 21 & 28 & 35 & 42 & 49 & 56 & 63 & 70 & 77 & 84 \\
\hline \multirow{3}{*}{ I } & 1.1 & $\mathrm{~N}$ & $\mathrm{~N}$ & $\mathrm{~N}$ & $\mathrm{~N}$ & $\mathrm{~N}$ & $\mathrm{~N}$ & $\mathrm{~N}$ & $\mathrm{~N}$ & $\mathrm{~N}$ & $\mathrm{~N}$ & $\mathrm{~N}$ & $\mathrm{~N}$ & $\mathrm{~N}$ & $\mathrm{~N}$ \\
\hline & 1.2 & $\mathrm{~N}$ & $\mathrm{~N}$ & $\mathrm{~N}$ & $\mathrm{~N}$ & $\mathrm{~N}$ & $\mathrm{~N}$ & $\mathrm{~N}$ & $\mathrm{~N}$ & $\mathrm{~N}$ & $\mathrm{~N}$ & $\mathrm{~N}$ & $\mathrm{~N}$ & $\mathrm{~N}$ & $\mathrm{~N}$ \\
\hline & 1.3 & $\mathrm{~N}$ & $\mathrm{~N}$ & $\mathrm{~N}$ & $\mathrm{~N}$ & $\mathrm{~N}$ & $\mathrm{~N}$ & $\mathrm{~N}$ & $\mathrm{~N}$ & $\mathrm{~N}$ & $\mathrm{~N}$ & $\mathrm{~N}$ & $\mathrm{~N}$ & $\mathrm{~N}$ & $\mathrm{~N}$ \\
\hline \multirow{3}{*}{ II } & 2.1 & $\mathrm{~N}$ & $\mathrm{~N}$ & $\mathrm{~N}$ & $\mathrm{~N}$ & $\mathrm{~N}$ & $\mathrm{~N}$ & $\mathrm{~N}$ & $\mathrm{~N}$ & $\mathrm{~N}$ & $\mathrm{~N}$ & $\mathrm{~N}$ & $\mathrm{~N}$ & $\mathrm{~N}$ & $\mathrm{~N}$ \\
\hline & 2.2 & $\mathrm{~N}$ & $\mathrm{~N}$ & $\mathrm{~N}$ & $\mathrm{~N}$ & $\mathrm{~N}$ & $\mathrm{~N}$ & $\mathrm{~N}$ & $\mathrm{~N}$ & $\mathrm{~N}$ & $\mathrm{~N}$ & $\mathrm{~N}$ & $\mathrm{~N}$ & $\mathrm{~N}$ & $\mathrm{~N}$ \\
\hline & 2.3 & $\mathrm{~N}$ & $\mathrm{~N}$ & $\mathrm{~N}$ & $\mathrm{~N}$ & $\mathrm{~N}$ & $\mathrm{~N}$ & $\mathrm{~N}$ & $\mathrm{~N}$ & $\mathrm{~N}$ & $\mathrm{~N}$ & $\mathrm{~N}$ & $\mathrm{~N}$ & $\mathrm{~N}$ & $\mathrm{~N}$ \\
\hline \multirow{3}{*}{ III } & 3.1 & $\mathrm{~N}$ & $\mathrm{~N}$ & $\mathrm{~N}$ & $\mathrm{~N}$ & $\mathrm{~N}$ & $\mathrm{~N}$ & $\mathrm{~N}$ & $\mathrm{~N}$ & $\mathrm{~N}$ & $\mathrm{~N}$ & $\mathrm{~N}$ & $\mathrm{~N}$ & $\mathrm{~N}$ & $\mathrm{~N}$ \\
\hline & 3.2 & $\mathrm{~N}$ & $\mathrm{~N}$ & $\mathrm{~N}$ & $\mathrm{~N}$ & $\mathrm{~N}$ & $\mathrm{~N}$ & $\mathrm{~N}$ & $\mathrm{~N}$ & $\mathrm{~N}$ & $\mathrm{~N}$ & $\mathrm{~N}$ & $\mathrm{~N}$ & $\mathrm{~N}$ & $\mathrm{~N}$ \\
\hline & 3.3 & $\mathrm{~N}$ & $\mathrm{~N}$ & $\mathrm{~N}$ & $\mathrm{~N}$ & $\mathrm{~N}$ & $\mathrm{~N}$ & $\mathrm{~N}$ & $\mathrm{~N}$ & $\mathrm{~N}$ & $\mathrm{~N}$ & $\mathrm{~N}$ & $\mathrm{~N}$ & $\mathrm{~N}$ & $\mathrm{~N}$ \\
\hline \multirow{3}{*}{ IV } & 4.1 & $\mathrm{~N}$ & $\mathrm{~N}$ & $\mathrm{~N}$ & $\mathrm{~N}$ & $\mathrm{~N}$ & $\mathrm{~N}$ & $\mathrm{~N}$ & $\mathrm{~N}$ & $\mathrm{~N}$ & $\mathrm{~N}$ & $\mathrm{~N}$ & $\mathrm{~N}$ & $\mathrm{~N}$ & $\mathrm{~N}$ \\
\hline & 4.2 & $\mathrm{~N}$ & $\mathrm{~N}$ & $\mathrm{~N}$ & $\mathrm{~N}$ & $\begin{array}{c}\text { PhI: N } \\
\text { PhII: } \\
++\end{array}$ & $\begin{array}{c}\text { PhI: N } \\
\text { PhII: } \\
++\end{array}$ & $\begin{array}{c}\text { PhI: N } \\
\text { PhII: } \\
++\end{array}$ & $\begin{array}{c}\text { PhI: N } \\
\text { PhII: } \\
++++\end{array}$ & $\begin{array}{c}\text { PhI: N } \\
\text { PhII: } \\
++++\end{array}$ & $\begin{array}{c}\text { PhI: N } \\
\text { PhII: } \\
++++\end{array}$ & $\begin{array}{c}\text { PhI: N } \\
\text { PhII: } \\
++++\end{array}$ & $\begin{array}{c}\text { PhI: N } \\
\text { PhII: } \\
+++\end{array}$ & $\begin{array}{c}\text { PhI: + } \\
\text { PhII: } \\
+++\end{array}$ & $\begin{array}{c}\text { PhI: + } \\
\text { PhII: } \\
+++\end{array}$ \\
\hline & 4.3 & $\mathrm{~N}$ & $\mathrm{~N}$ & $\mathrm{~N}$ & $\mathrm{~N}$ & $\mathrm{~N}$ & $\mathrm{~N}$ & $\mathrm{~N}$ & $\mathrm{~N}$ & $\mathrm{~N}$ & $\mathrm{~N}$ & $\mathrm{~N}$ & $\mathrm{~N}$ & $\mathrm{~N}$ & $\mathrm{~N}$ \\
\hline \multirow{3}{*}{ Control } & 5.1 & $\mathrm{~N}$ & $\mathrm{~N}$ & $\mathrm{~N}$ & $\mathrm{~N}$ & $\mathrm{~N}$ & $\mathrm{~N}$ & $\mathrm{~N}$ & $\mathrm{~N}$ & $\mathrm{~N}$ & $\mathrm{~N}$ & $\mathrm{~N}$ & $\mathrm{~N}$ & $\mathrm{~N}$ & $\mathrm{~N}$ \\
\hline & 5.2 & $\mathrm{~N}$ & $\mathrm{~N}$ & $\mathrm{~N}$ & $\mathrm{~N}$ & $\mathrm{~N}$ & $\mathrm{~N}$ & $\mathrm{~N}$ & $\mathrm{~N}$ & $\mathrm{~N}$ & $\mathrm{~N}$ & $\mathrm{~N}$ & $\mathrm{~N}$ & $\mathrm{~N}$ & $\mathrm{~N}$ \\
\hline & 5.3 & $\mathrm{~N}$ & $\mathrm{~N}$ & $\mathrm{~N}$ & $\mathrm{~N}$ & $\mathrm{~N}$ & $\mathrm{~N}$ & $\mathrm{~N}$ & $\mathrm{~N}$ & $\mathrm{~N}$ & $\mathrm{~N}$ & $\mathrm{~N}$ & $\mathrm{~N}$ & $\mathrm{~N}$ & $\mathrm{~N}$ \\
\hline
\end{tabular}

* complement fixation test; PhI - phase I; PhII - phase II; $\mathrm{N}$ - negative; + - haemolysis over $75 \%$; ++ - haemolysis between $50 \%$ and $75 \%$; +++

- haemolysis between $25 \%$ and $50 \%$; ++++- haemolysis below $25 \%$

Table 2. Results of real-time PCR for internal organs of guinea pigs

\begin{tabular}{|c|c|c|c|c|c|c|c|c|c|}
\hline \multirow[b]{2}{*}{ Group } & \multirow{2}{*}{$\begin{array}{l}\text { Animal } \\
\text { ID }\end{array}$} & \multicolumn{8}{|c|}{ Result of real-time PCR } \\
\hline & & heart & lungs & liver & spleen & stomach & $\begin{array}{c}\text { small } \\
\text { intestine }\end{array}$ & caecum & testes \\
\hline \multirow{3}{*}{ I } & 1.1 & negative & negative & negative & negative & negative & negative & negative & negative \\
\hline & 1.2 & negative & negative & negative & negative & negative & negative & negative & negative \\
\hline & 1.3 & negative & negative & negative & negative & negative & negative & negative & negative \\
\hline \multirow{3}{*}{ II } & 2.1 & negative & negative & negative & negative & negative & negative & negative & negative \\
\hline & 2.2 & negative & negative & negative & negative & negative & negative & negative & positive \\
\hline & 2.3 & negative & negative & negative & negative & negative & negative & negative & negative \\
\hline \multirow{3}{*}{ III } & 3.1 & negative & negative & negative & negative & negative & negative & negative & negative \\
\hline & 3.2 & negative & negative & negative & negative & negative & negative & negative & negative \\
\hline & 3.3 & negative & negative & negative & negative & negative & negative & negative & negative \\
\hline \multirow{3}{*}{ IV } & 4.1 & negative & negative & negative & negative & negative & negative & negative & negative \\
\hline & 4.2 & negative & negative & negative & negative & negative & negative & positive & negative \\
\hline & 4.3 & negative & negative & negative & negative & negative & negative & negative & negative \\
\hline \multirow{3}{*}{ Control } & 5.1 & negative & negative & negative & negative & negative & negative & negative & negative \\
\hline & 5.2 & negative & negative & negative & negative & negative & negative & negative & negative \\
\hline & 5.3 & negative & negative & negative & negative & negative & negative & negative & negative \\
\hline
\end{tabular}




\section{Discussion}

An inspiration for the study was limited and contradictory data about the possibility of C. burnetii transmission to humans by the alimentary route. Taking into account the large epidemic with more than 4,000 human cases of Q fever in the Netherlands from 2007 to 2010, the risk for public health is significant. Babudieri (2) refers to unpublished research indicating unsuccessful attempts at infection of 75 calves by giving them contaminated milk. The opposite result was obtained by Bell et al. (3), who infected two calves in the same way. The effectiveness of this oral inoculation was confirmed by the isolation of the pathogen from the calves' blood using guinea pigs. Durand (6) determined that in the case of mice, a 10,000 times higher $C$. burnetii dose is needed for alimentary than for intraperitoneal infection, whereas Kruszewska and TylewskaWierzbanowska (10) effectively inoculated mice with the same dose of bacteria, independently of the route of infection. Schaal (15) confirmed the presence of specific immunoglobulins in 8 out of 25 guinea pigs which received milk containing $C$. burnetii per os twice a day. Interestingly, seroconversion was not observed in individuals of which the mucous membrane of the stomach was irritated mechanically or chemically. In five out of eight seropositive animals, the presence of a viable pathogen in the internal organs (testes and spleen) was confirmed by inoculation of laboratory animals. Moreover, clinical symptoms of Q fever were observed in some experimental groups, but their type and severity were not described. Interestingly, they were recorded in a group of animals which did not produce specific antibodies. It was also not mentioned whether attempts were made to isolate the pathogen using tissues derived from seronegative individuals.

In this study animals from experimental groups did not exhibit any clinical symptoms that could indicate C. burnetii infection; however, the presence of pathogen DNA in the testes of one animal was confirmed. Moreover, another guinea pig had high levels of specific antibodies and the bacteria were also detected in the caecum of this animal. Similarly to Schaal's experiment (15), pathogen genetic material was found in testicular tissue, which indicates that the gastrointestinal mucosa barrier was overcome and $C$. burnetii spread haematogenously. No specific antibodies were detected in the blood of this individual. Perhaps in guinea pigs, as in humans, the appearance of specific immunoglobulins is preceded by the presence of bacteria in the blood, which would explain the presence of $C$. burnetii in the testicular tissue. It seems interesting that the animals did not develop clinical symptoms of the disease and seroconversion was noted only in one guinea pig. C. burnetii as an intracellular pathogen may avoid the immune response, and the body's response to infection with this microorganism may depend on the immune status $(18,20)$. The presence of $C$. burnetii in the testicular tissue may suggest that the pathogen can infect the organism via the alimentary route, infiltrate the cells and stay in them until there are favourable conditions for replication (i.e. immunosuppression). Research in this area should be continued including work using immunosuppressed animals as an experimental group. In order to evaluate the possibility of development of chronic disease, the experimental duration time might be prolonged. Moreover, genetically diverse C. burnetii strains might be used to investigate their pathogenic potential via the alimentary route.

Conflict of Interests Statement: The authors declare that there is no conflict of interests regarding the publication of this article.

Financial Disclosure Statement: This work was funded by the National Science Centre, Poland (grant number 2015/17/D/NZ7/00816).

Animal Rights Statement: The experiments on animals were conducted in accordance with the local Ethical Committee laws and regulations as regards care and use of experimental animals.

\section{References}

1. Agerholm J.: Coxiella burnetii associated reproductive disorders in domestic animals - a critical review. Acta Vet Scand 2013. doi: 10.1186/1751-0147-55-13.

2. Babudieri B.: Q fever: a zoonosis. Adv Ve Sci Comp Med 1959, 5, 82-182.

3. Bell E., Parker R., Stoenner H.: Q Fever. Experimental Q fever in cattle. Am J Public Health 1949, 39, 478-484.

4. Bewley K.: Animal models of Q fever (Coxiella burnetii). Comp Med 2013, 63, 469-476.

5. Capuano F., Mancusi A., Casalinuovo F., Perugini A., Proroga Y., Guarino A., Berri M.: Real-time PCR-based detection of Coxiella burnetii in cheeses. Eur Food Res Technol 2012, 235, 1181-1186.

6. Durand M.: Lacteal and placental excretion of Coxiella burnetii, agent of $\mathrm{Q}$ fever, in the cow. Importance and prevention. Bull Acad Natl Med 1993, 177, 935-945.

7. Enright J., Sadler W., Thomas R.: Pasteurization of milk containing the organism of Q fever. Am J Public Health Nations Health 1957, 47, 695-700.

8. Heggers J.P., Billups L.H., Hinrichs D.J., Mallavia L.P.: Pathophysiologic features of Q fever-infected guinea pigs. Am J Vet Res 1975, 36, 1047-1052.

9. Kruszewska D., Tylewska-Wierzbanowska S.: Isolation of Coxiella burnetii from bull semen. Res Vet Sci 1997, 3, 299-300.

10. Kruszewska D., Tylewska-Wierzbanowska S.: Dependence between penetration route and course of infection with Coxiella burnetii in mice. Med Dosw Mikrobiol 1992, 44, 145-152.

11. Lockhart M.G., Graves S.R., Banazis M.J., Fenwick S.G., Stenos J.: A comparison of methods for extracting DNA from Coxiella burnetii as measured by a duplex qPCR assay. Lett Appl Microbiol 2011, 52, 513-520.

12. Loftis A., Priestley R., Massung R.: Detection of Coxiella burnetii in commercially available raw milk from the United States. Foodborne Pathog Dis 2010, 7, 1453-1456.

13. Meredith A., Cleaveland S., Denwood M., Brown J., Shaw D.: Coxiella burnetii ( $\mathrm{Q}$ fever) seroprevalence in prey and predators in the United Kingdom: evaluation of infection in wild rodents, foxes, and domestic cats using a modified ELISA. Transbound Emerg Dis 2015, 62, 639-649.

14. Plummer P.J., McClure J.T., Menzies P., Morley P.S., Van den Brom R., Van Metre D.C.: Management of Coxiella burnetii infection in livestock populations and the associated 
zoonotic risk: a consensus statement. J Vet Intern Med 2018, 32, 1481-1494. doi.org/10.1111/jvim. 15229 .

15. Schaal E.: Animal experiments on the oral transmission of the pathogen of $\mathrm{Q}$ fever (Coxiella burnetii) by naturally infected milk. J Vet Med 1974, Series A suppl. 20, 245-248.

16. Scott G.H., Burger G.T., Kishimoto R.A.: Experimental Coxiella burnetii infection of guinea pigs and mice. Lab Anim Sci 1978, 28, 673-675.

17. Shah S., Kovacs C., Tan C., Pettersson G., Shrestha N., Lutwick L., Gordon S.: Delayed diagnosis of Q fever endocarditis in a rheumatoid arthritis patient. ID Cases 2015, 26, 94-96.

18. Sidwell R., Gebhardt L.: Studies of latent Q fever infections III. Effects of parturition upon latently infected guinea pigs and white mice. Am J Epidemiol 1966, 84, 132-137.
19. Signs K., Stobierski M., Gandhi T.: Q fever cluster among raw milk drinkers in Michigan, 2011. Clin Infect Dis 2012, 55, 1387-1389.

20. Stein A., Louveau C., Lepidi H., Ricci F., Baylac P., Davoust B., Raoult D.: Q fever pneumonia: virulence of Coxiella burnetii pathovars in a murine model of aerosol infection. Infect Immun 2005, 73, 2469-2477.

21. To H., Sakai R., Shirota K., Kano C., Abe S., Sugimoto T., Takehara K., Morita C., Takashima I., Maruyama T., Yamaguchi T., Fukushi H., Hirai K.: Coxiellosis in domestic and wild birds from Japan. J Wildl Dis 1998, 34, 310-316. 